\title{
Efflux transport of estrogen glucuronides by human MRP2, MRP3, MRP4 and BCRP
}

\section{Järvinen, Erkka}

2018-04

Järvinen , E , Deng , F , Kidron , H \& Finel , M 2018 , ' Efflux transport of estrogen

glucuronides by human MRP2, MRP3, MRP4 and BCRP ' , Journal of Steroid Biochemistry and Molecular Biology , vol. 178 , pp. 99-107 . https://doi.org/10.1016/j.jsbmb.2017.11.007

http://hdl.handle.net/10138/321530

https://doi.org/10.1016/j.jsbmb.2017.11.007

cc_by_nc_nd

acceptedVersion

Downloaded from Helda, University of Helsinki institutional repository.

This is an electronic reprint of the original article.

This reprint may differ from the original in pagination and typographic detail.

Please cite the original version. 
1 EFFLUX TRANSPORT of ESTROGEN GLUCURONIDES by HUMAN MRP2, MRP3, MRP4 and 2 BCRP

3

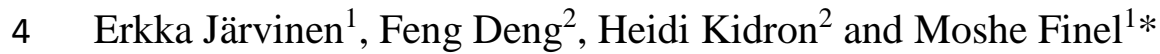

$5 \quad{ }^{1}$ Division of Pharmaceutical Chemistry and Technology, ${ }^{2}$ Division of Pharmaceutical Biosciences,

6 Faculty of Pharmacy, University of Helsinki, Finland

7

8 Corresponding Author:

9 *Moshe Finel, Division of Pharmaceutical Chemistry and Technology, Faculty of Pharmacy,

University of Helsinki, 00014 University of Helsinki, Finland,

moshe.finel@helsinki.fi

\section{Abbreviations:}

estrone sulfate $\left(E_{1}-S\right)$, estrone glucuronide $\left(E_{1}-G\right)$, estradiol-3-glucuronide $\left(E_{2}-3 G\right)$, estradiol-17 $\beta$ glucuronide $\left(E_{2}-17 G\right)$, estriol-3-glucuronide $\left(E_{3}-3 G\right)$, estriol-16 $\alpha$-glucuronide $\left(E_{3}-16 G\right)$, breast cancer resistance protein (BCRP, $\mathrm{ABCG} 2)$, multidrug resistance associated proteins (MRP, $\mathrm{ABCC}$ ), multidrug resistance protein 1 (MDR1, P-glycoprotein, P-gp), UDP-glucuronosyltransferases (UGT), ATP-

25 binding cassette transporters (ABC) 
3 Estrone, estradiol and estriol are endogenous human estrogens that are rapidly conjugated with 4 glucuronic acid in both intestinal and hepatic epithelial cells. The resulting glucuronides, estrone-35 glucuronide ( $\left.E_{1}-\mathrm{G}\right)$, estradiol-3- and 17-glucuronides ( $\mathrm{E}_{2}-3 \mathrm{G}$ and $\left.\mathrm{E}_{2}-17 \mathrm{G}\right)$, as well as estriol-3- and 166 glucuronides $\left(\mathrm{E}_{3}-3 \mathrm{G}\right.$ and $\left.\mathrm{E}_{3}-16 \mathrm{G}\right)$ are found in human plasma and urine. Unlike $\mathrm{E}_{2}-17 \mathrm{G}$, the efflux 7 transport of other estrogen glucuronides by human transporters has not yet been investigated 8 comprehensively. We have studied the transport of $E_{1}-G, E_{2}-3 G, E_{3}-3 G, E_{3}-16 G$ and estrone-3-sulfate 9 (E $1-\mathrm{S})$, another important estrogen conjugate, using the vesicular transport assay with recombinant human MRP2, MRP3, MRP4, MDR1 and BCRP that were expressed in insect cells. The transport screening assays revealed that whereas $\mathrm{E}_{1}-\mathrm{S}$ was a good and specific substrate for BCRP, the less transporter-specific conjugates, $\mathrm{E}_{1}-\mathrm{G}$ and $\mathrm{E}_{2}-3 \mathrm{G}$, were still transported by BCRP at 10-fold higher rates than $\mathrm{E}_{1}-\mathrm{S}$. BCRP also transported $\mathrm{E}_{3}-16 \mathrm{G}$ at higher rates than the studied MRPs, while it transported $\mathrm{E}_{3}-$ $3 \mathrm{G}$ at lower rates than MRP3. MRP2 exhibited lower or equal transport rates of $\mathrm{E}_{1}-\mathrm{G}, \mathrm{E}_{2}-3 \mathrm{G}, \mathrm{E}_{3}-3 \mathrm{G}$ and $\mathrm{E}_{3}-16 \mathrm{G}$ compared to MRP3 and BCRP in the screening assays, mainly due to its high $K_{\mathrm{m}}$ values, between 180 and $790 \mu \mathrm{M}$. MRP3 transported all the tested glucuronides at rather similar rates, and exhibiting $K_{\mathrm{m}}$ values below $20 \mu \mathrm{M}$ but lower $\mathrm{V}_{\max }$ values than other transporters. In the case of $\mathrm{E}_{3}-3 \mathrm{G}, \mathrm{MRP} 3$ was the most active transporter in the screening assay. MRP4 transported only $\mathrm{E}_{3}-16 \mathrm{G}$ at considerable rates and no transport of any tested estrogen conjugates was detected by MDR1. These new results, in combination with previously reported in vivo human data, stimulates our understanding on the substrate specificity and role of efflux transporters in disposition of estrogen glucuronides in humans. 
1 Keywords: drug transporters, steroid disposition, steroid transport, estrogen, glucuronides, steroid

2 excretion

3

4

5 Estrogens are important endogenous steroids that play fundamental roles in numerous body functions [1,

6 2]. In addition, estrogens are widely used as drugs, in both contraception and hormone replacement

7 therapies. Homeostasis and metabolism of estrogens are complex processes that are regulated by

oxidative and reductive metabolism (phase I), as well as conjugative metabolism (phase II), resulting in over hundred different biotransformation products in human [3, 4]. The most important naturally occurring estrogens in women are estriol $\left(E_{3}\right)$, estradiol $\left(E_{2}\right)$ and estrone $\left(E_{1}\right)$. Conjugation of estrogens with glucuronic acid (i.e. glucuronidation), is catalyzed by several different UDPglucuronosyltransferase enzymes (UGTs) and results in estrogen glucuronides. These glucuronides are regarded as end products of estrogen metabolism and they are excreted from the body without further biotransformation. Glucuronidation of estrogens takes place in various tissues, including the most prominent metabolizing tissues, namely liver, intestine and kidney [4]. The estrogen metabolizing UGTs, such as UGT1A1, UGT1A10 and UGT2B7, are expressed at different levels and in a tissue-specific manner, resulting in variable glucuronidation rates and specificities among different tissues.

Disposition of estrogen glucuronides has a characteristic feature of bile excretion, followed by extensive enterohepatic circulation, which highlights not only the role of metabolizing enzymes but also the role of active efflux transport of the conjugated estrogens in the liver [5, 6]. However, despite extensive bile excretion and enterohepatic circulation of estrogen conjugates, high amounts of conjugated estrogens are also found in the human blood circulation and are excreted, eventually, via urine [7, 8]. Estrone-3glucuronide $\left(E_{1}-G\right)$, estradiol-3- and estradiol-17-glucuronide ( $E_{2}-3 G$ and $\left.E_{2}-17 G\right)$, estriol-3 and estriol- 
1 16-glucuronide ( $\mathrm{E}_{3}-3 \mathrm{G}$ and $\left.\mathrm{E}_{3}-16 \mathrm{G}\right)$ are the glucuronosyl conjugates of estrone, estradiol and estriol,

2 respectively (Fig. 1). Estrone sulfate $\left(E_{1}-S\right)$ is the most abundant estrogen conjugate in the blood

3 circulation and, possibly, acting as a reservoir for free estrogens [3, 4, 7]. The concentration of $\mathrm{E}_{1}-\mathrm{S}$

$4 \quad$ varies in healthy individuals between $0.5-5 \mathrm{nM}$, but up to $180 \mathrm{nM}$ has been measured during pregnancy

5 [7, 8, 9]. The plasma concentration of estrogen glucuronides is generally over ten-fold lower, with

6 increased concentrations during pregnancy, similarly as for $\mathrm{E}_{1}-\mathrm{S}$.

$7 \quad$ (Figure 1)

8 Human ATP-binding cassette (ABC) transporters are a family of multiple efflux transporters that utilize

9 ATP to actively transport compounds across biological membranes $[10,11]$. ABC transporters include 10 several pharmacologically, but especially pharmacokinetically, relevant transporters that are localized on 11 plasma membranes of polarized cells [11]. Among them are the multidrug resistance associated proteins $12 \quad 2,3$ and $4(\mathrm{MRP} 2-4, A B C C 2-4)$ and the breast cancer resistance protein (BCRP, $A B C G 2)$, which are localized on either the apical or basolateral membranes of human enterocytes, hepatocytes and proximal tubular cells $[12,13]$. They contribute to systemic exposure and biliary, intestinal and urinary excretion of their substrates that mostly are anionic and include glucuronide conjugates of drugs, other xenobiotics, as well as endogenous compounds [14]. MRP2 and BCRP are expressed on apical membranes in both hepatocytes and enterocytes, where they restrict systemic exposure of their substrates [12, 13]. MRP3 is localized on the opposite membranes, basolateral, in the same polarized cells, contributing to systemic exposure of its substrates. MRP4 is also expressed on basolateral membranes of hepatocytes and enterocytes, but it might have a more prominent role in the kidneys, where it is expressed on luminal membranes of the proximal tubular cells, by contributing to active secretion of its substrates into urine 
1 Not much is currently known about the interactions of $E_{1}-G, E_{2}-3 G, E_{3}-3 G$ and $E_{3}-16 G$ with the human 2 transporters MRP2, MRP3, MRP4 and BCRP. Contrary to the above, the transport of $\mathrm{E}_{2}-17 \mathrm{G}$ has been 3 well characterized and it is a prominent substrate for all of the above transporters, as well as for several 4 uptake and other efflux transporters $[14,17]$. In addition, the transport of $E_{2}-17 \mathrm{G}$ by multidrug resistance 5 protein 1 (MDR1, P-glycoprotein, $\mathrm{P}$-gp) is reported, although this transporter is not generally considered 6 to be involved in the transport of phase II conjugates $[14,18]$. On the other hand, $\mathrm{E}_{1}-\mathrm{S}$ is a very good and 7 widely used substrate for BCRP, as well as for several uptake transporters $[14,17]$. Of the four estrogen 8 glucuronides included in this study, $\mathrm{E}_{2}-3 \mathrm{G}$ was previously reported to be a rather good substrate for 9 MRP2, but to lack the distinctive cooperative transport kinetics which is typical for the transport of $\mathrm{E}_{2}-$ 10 17G by MRP2 [19].

11 We have now studied the efflux transport of physiologically important estrogen conjugates $E_{1}-G_{1}, E_{1}-S$ $\mathrm{E}_{2}-3 \mathrm{G}, \mathrm{E}_{3}-3 \mathrm{G}$ and $\mathrm{E}_{3}-16 \mathrm{G}$ (Fig. 1) by recombinant human transporters MRP2, MRP3, MRP4, MDR1 and BCRP, using the membrane vesicle transport assay. Our aims were to explore the substrate specificity and kinetic differences between these transporters, in vitro, in order to improve the understanding of estrogen conjugate disposition in vivo. The results add to the scarce knowledge of steroid conjugates transport by human efflux transporters, an important topic in cancer and drug research. 


\section{$2 \quad 2.1$ Chemicals and solvents}

3 Sodium salts of $E_{2}-17 G, E_{3}-3 G$ and $E_{1}-S$, as well as $E_{3}-16 G$ were from Sigma Aldrich (St. Louis, MO,

4 USA), sodium salt of $\mathrm{E}_{1}-\mathrm{G}$ was from Toronto Research Chemicals (Toronto, ON, Canada) and sodium

5 salt of $\mathrm{E}_{2}-3 \mathrm{G}$ from Cayman Chemical (Ann Arbor, MI, USA). Tritium-labelled $\mathrm{E}_{1}-\mathrm{S}\left(6\right.$, 7- ${ }^{3} \mathrm{H}$, as 6 ammonium salt, specific activity $54 \mathrm{mCi} / \mu \mathrm{mol}$ ) and the liquid scintillation cocktail (Optiphase Hisafe 3)

7 were from Perkin Elmer (Waltham, MA, USA). All solvents and formic acid were of analytical grade or

8 better and were obtained from Sigma-Aldrich. Water for the analyses and assays was purified using Milli-

9 Q water purification system and filtered through $0.22 \mu \mathrm{M}$ filter (Merck Millipore, Darmstadt, Germany).

\subsection{Expression and vesicle preparation of human MRP2, MRP3, MRP4, MDR1 and BCRP}

The human recombinant transporters MRP2, MRP3, MRP4, MDR1 and BCRP were expressed in baculovirus-infected $S f 9$ insect cells and inside-out membrane vesicles were prepared from them and used for the vesicular transport assays (see section 2.3) as previously described [20-24]. In addition, control vesicles $\left(\mathrm{Ctrl}^{\mathrm{M}}\right.$ for MRP2-MRP4 and $\mathrm{Ctrl}^{+\mathrm{C}}$ for MDR1 and BCRP, see below) were prepared from Sf9 insect cells that were transfected with baculovirus containing no human cDNA.

MDR1 and BCRP vesicles were supplemented with additional cholesterol to enhance their transport activity, as reported previously [25, 26] and carried out in our laboratory [21-24]. Accordingly, cholesterol loaded control vesicles $\left(\mathrm{Ctrl}^{+\mathrm{C}}\right)$ were used as controls in MDR1 and BCRP assays.

\subsection{Vesicular transport assays}

The vesicular transport assays were carried out in 96-well polystyrene plates at a final volume of $75 \mu 1$ per well, as previously described [19, 20,21, 22]. The assay mixture consisted of $40 \mathrm{mM}$ MOPS (adjusted to $\mathrm{pH} 7.0$ with Tris- $\mathrm{HCl}), 6 \mathrm{mM} \mathrm{MgCl}_{2}, 60 \mathrm{mM} \mathrm{KCl}, 7 \mathrm{mM}$ Tris- $\mathrm{HCl}, 7 \mathrm{mM}$ mannitol and $0.3 \mathrm{mM}$ 
1 EGTA. The total vesicle protein amount in the assays were either $40 \mu \mathrm{g}$ (MRP2, MRP3, MRP4, MDR1

2 and $\left.\mathrm{Ctrl}^{\mathrm{M}}\right)$ or $20 \mu \mathrm{g}\left(\mathrm{BCRP}\right.$ and $\left.\mathrm{Ctrl}^{+\mathrm{C}}\right)$ per well. The substrate stock solutions were prepared in DMSO,

3 at $50 \mathrm{mM}$ concentration, and stored at $-20{ }^{\circ} \mathrm{C}$. Subsequent substrate dilutions were done in the assay

4 buffer (MOPS- $\mathrm{MgCl}_{2}-\mathrm{KCl}$ ), resulting in a final DMSO concentration of either $0.02 \%$ (initial screening

5 assays) or $1.0 \%$ (kinetic assays) in the transport assay.

6 Transport assay mixtures were prepared on ice prior the pre-incubation at $37{ }^{\circ} \mathrm{C}$ for $10 \mathrm{~min}$. Transport

7 reactions were initiated by the addition of either $\mathrm{Mg}$-ATP to a final concentration of $4 \mathrm{mM}(+\mathrm{ATP}$

8 samples) or blank reaction mixture (-ATP samples), both pre-incubated at $37^{\circ} \mathrm{C}$. The transport assays,

9 following initiation, were carried out for pre-determined times (1-6 min, see figure legends for the incubation time of each experiment) at $37{ }^{\circ} \mathrm{C}$ and constant shaking at $500 \mathrm{rpm}$. For kinetic assays, the incubation times were selected based on the linear transport of each substrate-transporter combination (See data in the supplementary material, Fig. S1). The transport reactions were quenched by adding 200 $\mu 1$ of cold buffer (70 mM KCl and $40 \mathrm{mM}$ MOPS $\mathrm{pH} 7.0)$ and were transferred to a 96-well filter plate (pore size $1.0 \mu \mathrm{m}$, glass fiber filters, from Merck Millipore, Darmstadt, Germany). The samples were then filtered and washed with five aliquots of the same cold buffer under vacuum filtration. The filter plate was subsequently dried at room temperature, after which $100 \mu \mathrm{l}$ of $1: 1$ acetonitrile: $0.2 \%$ formic acid in water, containing $\mathrm{E}_{2}-17 \mathrm{G}$ as internal standard, was applied to each well. The plate was then incubated at room temperature for 30-60 min under gentle shaking. Finally, the filter plate was centrifuged for 2 min at $3000 \mathrm{~g}$ to collect the samples (filtrate) into a new well plate and the samples were subjected to analysis by LC-MS/MS (see section 2.4).

Unlike the estrogen glucuronides, the transport of $\mathrm{E}_{1}-\mathrm{S}$ was assayed using a radioactively labelled compound. In this case, the transport assays included 1-150 nCi of tritium labelled $\mathrm{E}_{1}-\mathrm{S}$ per well. The transport reactions were carried out as described above for the estrogen glucuronides, but quantification 
1 of $E_{1}-S$ was done by the addition of $50 \mu 1$ scintillation cocktail to each well, followed by incubation of

2 the plate at room temperature for 30 min before radioactivity counting using a Microbeta 1450 Trilux

3 scintillation counter (from Wallac, Turku, Finland). In addition, when labelled $\mathrm{E}_{1}-\mathrm{S}$ was used the filter-

4 plate was pre-soaked, before transferring the assay samples, with $100 \mu 1$ of $50 \mu \mathrm{M}$ unlabeled $\mathrm{E}_{1}-\mathrm{S}$ to

5 decrease the unspecific binding of labelled compound.

6 Transport assays were conducted in triplicate samples for each time and concentration point, including

7 both + ATP and - ATP samples. The experimental data are reported as means \pm SD of retained compound

8 within the vesicles per amount of total vesicle protein per incubation time, resulting in $\mathrm{pmol} / \mathrm{min} / \mathrm{mg}$ total

9 protein values. Kinetic assays were conducted using at least six different substrate concentrations and

the data are reported as means of ATP-dependent transport \pm SD after subtracting the $-\mathrm{ATP}$ values from the +ATP values. Kinetic data were fitted to the Michaelis-Menten equation $\left(v=V_{\max }[\mathrm{S}] /\left([\mathrm{S}]+K_{\mathrm{m}}\right)\right)$, using least squares fit in GraphPad Prism 5 software (GraphPad Software, La Jolla, CA, USA), that was used also for data visualization. The goodness of fit was inspected in each case visually, using the EadieHofstee transformation of the experimental data (Suppl. Fig. 2), as well as the coefficient of determination $\left(R^{2}\right)$ value of the fit (Table 1). In addition, linear substrate transport versus concentration, in the absence of ATP (passive), was inspected to exclude artifacts, such as solubility limitations, during the assays. The substrate solubility in the reaction mixtures, at the used concentrations, was tested before the transport assays by HPLC analyses, visual inspection and nephelometer analyses (Nepheloskan Ascent, Labsystems, Finland).

\subsection{Analytical methods}

The amounts of $E_{1}-G, E_{2}-3 G, E_{3}-3 G$ and $E_{3}-16 G$ that was retained in the vesicles at the end of the transport assays, were quantified by triple quadrupole mass spectrometry (Xevo TQ-S), connected to an 
1 USA). Samples on a 96-well plate (kept at $15^{\circ} \mathrm{C}$ ) were injected (1-5 $\left.\mu 1\right)$ into Acquity UPLC BEH C18

$2(2.1 \times 100 \mathrm{~mm}, 1.7 \mu \mathrm{m}$ from Waters $)$ column that was kept at $30{ }^{\circ} \mathrm{C}$ and operated at a flow rate of 0.4

$3 \mathrm{ml} / \mathrm{min}$. The chromatography eluents were water (A) and acetonitrile (B), both containing $0.1 \%$ formic

4 acid. The gradient program (0-2.5 min $10 \% \mathrm{~B}$ to $65 \% \mathrm{~B}, 2.5-4 \mathrm{~min} 95 \% \mathrm{~B}$ followed by at least $1 \mathrm{~min}$ 5 equilibrium at $10 \% \mathrm{~B}$ ) was used to elute $\mathrm{E}_{3}-3 \mathrm{G}, \mathrm{E}_{3}-16 \mathrm{G}, \mathrm{E}_{2}-3 \mathrm{G}, \mathrm{E}_{2}-17 \mathrm{G}$ (internal standard) and $\mathrm{E}_{1}-\mathrm{G}$ at $6 \quad 1.33,1.72,1.95,2.08$ and 2.16 min, respectively.

7 The mass spectrometry was operated in negative electrospray ionization mode, using nitrogen as ion 8 source gas and argon as collision gas, both from Aga (Espoo, Finland). The operation parameters were set as following: capillary voltage at $-2.0 \mathrm{kV}$, cone at $1.0 \mathrm{~V}$, source offset at $50 \mathrm{~V}$, source temperature at $150{ }^{\circ} \mathrm{C}$, cone gas flow at $150 \mathrm{l} / \mathrm{h}$, nebulizer gas pressure at $7.0 \mathrm{bar}$, as well as desolvation gas temperature and flow rate at $650{ }^{\circ} \mathrm{C}$ and $1100 \mathrm{l} / \mathrm{h}$, respectively. Quantification was done using MS/MS mode, by selecting deprotonated precursor ions $[\mathrm{M}-\mathrm{H}]^{-}$at the first quadrupole $\left(463.2 \mathrm{~m} / \mathrm{z}\right.$ for $\mathrm{E}_{3}-3 \mathrm{G}$ and $\mathrm{E}_{3}-16 \mathrm{G}$, $447.2 \mathrm{~m} / \mathrm{z}$ for $\mathrm{E}_{2}-3 \mathrm{G}$ and $\mathrm{E}_{2}-17 \mathrm{G}$ and $445.2 \mathrm{~m} / \mathrm{z}$ for $\left.\mathrm{E}_{1}-\mathrm{G}\right)$, fragmenting them at the second quadrupole (collision energies were $45 \mathrm{~V}, 30 \mathrm{~V}, 35 \mathrm{~V}, 28 \mathrm{~V}$ and $38 \mathrm{~V}$ for $\mathrm{E}_{3}-3 \mathrm{G}, \mathrm{E}_{3}-16 \mathrm{G}, \mathrm{E}_{2}-3 \mathrm{G}, \mathrm{E}_{2}-17 \mathrm{G}$ and $\mathrm{E}_{1}-\mathrm{G}_{\text {, }}$ respectively) and monitoring the product ions resulting from the loss of glucuronic acid [M-H-176] $]^{-}$ (287.2 m/z for $E_{3}-3 G$ and $E_{3}-16 G, 271.2 \mathrm{~m} / \mathrm{z}$ for $E_{2}-3 G$ and $E_{2}-17 G$, as well as $269.2 \mathrm{~m} / \mathrm{z}$ for $\left.E_{1}-G\right)$. An additional product ion at $113.0 \mathrm{~m} / \mathrm{z}$, for qualitative confirmation, was monitored for all the analytes using 20-30 V collision energies. Dwell time was $100 \mathrm{~ms}$ for all the monitored reactions.

The ratio of analyte to internal standard $\left(\mathrm{E}_{2}-17 \mathrm{G}\right)$ was used for the quantification. The standard curve samples were prepared similarly to the test samples, namely in $100 \mu$ l of $1: 1$ acetonitrile: $0.2 \%$ formic acid in a water containing $\mathrm{E}_{2}-17 \mathrm{G}$ as internal standard and filtered through pre-wetted and dried filter 
1 compound, usually the lower limit for quantification was $1 \mathrm{nM}$ and the upper limit of quantification was $2 \quad 1000-5000 \mathrm{nM}$, depending on the analyte. 
1

\section{$2 \quad 3.1$ Screening of estrogen conjugate transport}

3 The transport of estrogen glucuronides and $E_{1}-\mathrm{S}$ (see structures in Fig. 1) was first tested using a single

4 substrate concentration of $10 \mu \mathrm{M}$ (for time-dependent transport, also when no transport activity was

5 found, of the all tested estrogen conjugates and transporters, see Supplementary figure S1). The results

6 of the initial screening experiment clearly showed that $E_{1}-S$ was not transported by any of the tested

7 MRPs (Fig. 2A). Even the addition of $5 \mathrm{mM}$ glutathione (GSH) to the transport assays did not change

8 this (results not shown). In sharp contrast to the MRPs, BCRP transported $\mathrm{E}_{1}-\mathrm{S}$ at high rates (Fig. 2A),

9 in agreement with previous reports $[14,27]$.

BCRP was also highly active in the transport of $\mathrm{E}_{1}-\mathrm{G}$ (Fig. 2B) and $\mathrm{E}_{2}-3 \mathrm{G}$ (Fig. 2C). In the case of estriol glucuronides, however, BCRP exhibited much lower activity toward $E_{3}-3 G$ in comparison to $E_{1}-G_{\text {and }}$ $\mathrm{E}_{2}-3 \mathrm{G}$ (Fig. 2D). On the other hand, BCRP transported $\mathrm{E}_{3}-16 \mathrm{G}$ at higher rates than each of the studied MRPs, but the rate was still clearly lower than in the case of $E_{1}-S, E_{1}-G$ and $E_{2}-3 G$ (Fig. 2E).

(Figure 2)

The transport activity of MRP2 in the initial screening toward $E_{1}-G$ and $E_{3}-G$ was lower in comparison to $E_{2}-3 G$ and $E_{3}-16 G$ (Fig. 2B-E). However, even in both latter cases the activity of MRP2 was clearly lower than the activity of BCRP and similar to the rates exhibited by MRP3 (Figs. 2B and 2C).

MRP3 transported all of the tested estrogen glucuronides at rather similar rates, at least under the conditions of the initial screening experiments where the substrate concentration was $10 \mu \mathrm{M}$ (Figs. 2B2E). MRP4, on the other hand, transported only $\mathrm{E}_{3}-16 \mathrm{G}$ at considerable rates (Fig. 2B-E), exhibiting quite clear and narrow selectivity in the transport of the studied estrogen glucuronides. Of the transporters 
1 included in this study, MDR1 was the only one not transporting any of the tested estrogen conjugates

2 (Fig. 2 and Supplementary figure S1).

3 It should be noted here that rate comparisons between different efflux transporters in this study, 4 particularly when the differences are not very large, should be considered with care. Presently, we do not

5 have a method to accurately measure the amount of active transporter in the vesicle preparations. On the

6 other hand, the transport rates of different substrates by the same transporter could be compared reliably

7 in this study, since they were done with the same vesicle preparation.

\section{$8 \quad 3.2$ Kinetic analysis of estrogen conjugate transport}

9 Kinetic analyses were carried out for all the tested transporters that exhibited substantial activity in the initial screening assay (Fig. 2). The kinetic curves are presented for each transporter separately (Figs. 3-

5) and the derived kinetic constants of the fitted model are listed in Table 1.

The kinetic assay results of BCRP transport of $\mathrm{E}_{1}-\mathrm{G}$ and $\mathrm{E}_{2}-3 \mathrm{G}$ (Fig. 3A) revealed that this transporter reaches higher $\mathrm{V}_{\max }$ values with these glucuronides than any other studied transporter, while its $\mathrm{K}_{\mathrm{m}}$ values are in the moderate range, below $100 \mu \mathrm{M}$ (Table 1 ). In the case of $\mathrm{E}_{1}-\mathrm{S}$, the $\mathrm{K}_{\mathrm{m}}$ value for BCRP was very low, 1.2 $\mu \mathrm{M}$ (Fig. 3B and Table 1). However, the $\mathrm{V}_{\max }$ of $\mathrm{E}_{1}-\mathrm{S}$ transport by BCRP was around 10-fold lower than for $E_{1}-G$ and $E_{2}-3 G$, whereas the $K_{m}$ values for these estrogen glucuronides, although in the moderate range, were over 60 -fold larger than for $\mathrm{E}_{1}-\mathrm{S}$ transport by BCRP (Table 1). The transport kinetics of $\mathrm{E}_{3}-3 \mathrm{G}$ by BCRP was not saturable at the studied concentrations (Fig. 3C), a result that is in agreement with the initial screening result that revealed lower transport rates of this glucuronide by BCRP (Fig. 2D). Contrary to $\mathrm{E}_{3}-3 \mathrm{G}$, the transport of $\mathrm{E}_{3}-16 \mathrm{G}$ by BCRP was saturable at low concentrations, yielding a low $\mathrm{K}_{\mathrm{m}}$ value of $29 \mu \mathrm{M}$ (Fig. 3C and Table 1), but also a $\mathrm{V}_{\max }$ value in the 
1 same range as for the transport of $\mathrm{E}_{1}-\mathrm{S}$, namely much lower than the $\mathrm{V}_{\max }$ values of BCRP transport for

$2 \mathrm{E}_{3}-3 \mathrm{G}$ or $\mathrm{E}_{1}-\mathrm{G}$ and $\mathrm{E}_{2}-3 \mathrm{G}$ (Table 1).

3

4 5

(Figure 3)

MRP2 exhibited lower active transport rates of $E_{1}-G, E_{2}-3 G, E_{3}-3 G$ and $E_{3}-16 G$ in the initial screening assays (Figs. 2B-E) and the kinetic analyses (Fig. 4) suggest that the prime reason for this was higher $\mathrm{K}_{\mathrm{m}}$ values in comparison to other transporters, particularly in the cases of estriol glucuronides, not lower $\mathrm{V}_{\max }$ values (Table 1). The transport kinetics of the studied estrogen glucuronides by MRP2 followed the Michaelis-Menten equation (Fig. 4, Table 1 and Suppl. Fig 2) and no indication of cooperative kinetics for MRP2 was found, when the data was analyzed by Eadie-Hofstee transformations (Suppl. Fig. 2). MRP2 follows such a cooperative kinetics in the transport of $\mathrm{E}_{2}-17 \mathrm{G}$, another estrogen glucuronide [14].

(Figure 4)

The transport of estrogen glucuronides by MRP3 differed from the other tested transporters by its nearly similar rates for all the tested glucuronides in the initial screening assays (Fig. 2B-E). The kinetic analyses (Figs. 5A and 5B) further revealed that in the case of MRP3, there were no large differences between the transport kinetics of the studied estrogen glucuronides. The maximal transport velocities varied by no more than two-fold and the $K_{\mathrm{m}}$ values ranged from 2.8 to $18.2 \mu \mathrm{M}$ (Table 1), demonstrating similar transport activity for $E_{1}-G, E_{2}-3 G, E_{3}-3 G$ and $E_{3}-16 G$ by MRP3. These results also indicate that the affinity of MRP3 for the transport of all the tested estrogen glucuronides is higher than the corresponding values for BCRP and MRP2, even if the $\mathrm{V}_{\max }$ values of MRP3 are generally lower.

(Figure 5)

Among the tested transporters, only MRP4 exhibited selective transport of only one of the studied compounds, $\mathrm{E}_{3}-16 \mathrm{G}$, at substantial rates (Fig. 2). Kinetic analysis revealed that this transport follows the 
1 Michaelis-Menten equation and both the $K_{m}$ and the $V_{\max }$ values of MRP4 are higher than the 2 corresponding values for $\mathrm{E}_{3}-16 \mathrm{G}$ transport by MRP3 (Fig. 5C and Table 1).

3 
1

2 The most frequently used substrate for efflux transporters, $E_{2}-17 G$, is an estrogen glucuronide [14]. In 3

\section{DISCUSSION}

this study, however, we have examined the transport of four other estrogen glucuronides and an estrogen sulfate, by the ATP-dependent efflux transporters MRP2, MRP3, MRP4, MDR1 and BCRP. Our results reveal new information on the substrate specificity of the transporters and differences between them in this respect. It is essential to consider these results taking into account the location of each transporter in polarized epithelial cells of human intestine, liver and kidney (Fig. 6), since this could determine and affect the disposition of the studied estrogen conjugates in vivo.

While we cannot directly compare the transport rates and $\mathrm{V}_{\max }$ values by the recombinant transporters to each other, since expression levels may differ somewhat among vesicle preparations, the changes in these values from one substrate to another and the magnitude of the values are clearly informative. In addition, the kinetic analyses provide indications on respective affinity to the substrates and how it differs among transporters and between substrates.

(Figure 6)

\subsection{Transport of $E_{1}-S$}

No transport of $\mathrm{E}_{1}-\mathrm{S}$ was observed by any other transporters studied here except BCRP that transported $\mathrm{E}_{1}-\mathrm{S}$ at a high affinity, as suggested by the low $K_{\mathrm{m}}$ value (Figs. $2 \mathrm{~A}$ and $3 \mathrm{~B}$, and Table 1). The $\mathrm{E}_{1-\mathrm{S}}$ transport results are in line with previously published findings for BCRP, MRP2 and MRP3 [27-29]. Like MRP2 and MRP3, the additional efflux transporter included in this study, MRP4, also did not exhibit transport activity toward $\mathrm{E}_{1}-\mathrm{S}$ (Fig. 2A). It may be interesting to note that similar results were previously found for the sulfate metabolite of the synthetic estradiol derivative, ethinylestradiol sulfate that was transported by BCRP, but not by MRP2, MRP3 or MRP4 [30, 31]. 
1 Since $\mathrm{E}_{1}-\mathrm{S}$ is found at high amounts in the bile [32], apical excretion in the liver could be explained by

2 BCRP that solely transported this compound (Figs. 2A and 3B, and Table 1). Nonetheless, E $1-\mathrm{S}$ is also

3 found in the human blood circulation, suggesting that a basolateral transport from the liver takes place,

4 in addition to the apical transport into bile [4, 7]. Hence, an interesting question is how $\mathrm{E}_{1}-\mathrm{S}$ crosses the basolateral membranes of the liver. MRP4 could have been a candidate transporter for this transport since it carries steroid sulfates such as dehydroepiandrosterone sulfate [14]. However, under our experimental conditions no $\mathrm{E}_{1}-\mathrm{S}$ transport by MRP4, neither by the other basolateral transporter MRP3, was observed (Fig. 2A). Thus, it is likely that other basolateral transporters are involved in the systemic excretion of

$9 \quad \mathrm{E}_{1}-\mathrm{S}$ in human. It has actually been reported that MRP1 and OST $\alpha / \beta$ transport $\mathrm{E}_{1}-\mathrm{S}$ in vitro and this might explain the hepatic in vivo basolateral transport of $\mathrm{E}_{1}-\mathrm{S}$, although the former transporter may be expressed at low levels in healthy human livers [33-36]. Further studies are needed to fully clarify this issue.

\subsection{Transport and disposition of $E_{1}-G$ and $E_{2}-3 G$}

In the human intestine, estrone undergoes direct glucuronidation and sulfation, whereas in the liver only estrone sulfation is catalyzed at high rates $[37,38]$. Estrone glucuronidation is catalyzed almost only by the extrahepatic UGT1A10 [38], while its sulfonation is primarily catalyzed by the high-affinity sulfotransferase SULT1E1 that is expressed in both the liver and small intestine [37]. Obviously, the expression level of UGTs and SULTs in different tissues have an effect on the over 10-fold higher concentrations of $\mathrm{E}_{1}-\mathrm{S}$ than $\mathrm{E}_{1}-3 \mathrm{G}$ in human plasma [7, 39]. However, intestinal and hepatic efflux transporters, including their localization in the plasma membranes may also contribute to relative plasma levels of estrone glucuronide and sulfate. Unlike estrone, estradiol is mainly glucuronidated in the liver resulting in $\mathrm{E}_{2}-17 \mathrm{G}$ as the main glucuronide and $\mathrm{E}_{2}-3 \mathrm{G}$ as a minor product $[40,41]$. In the intestine, however, estradiol is almost exclusively glucuronidated to $\mathrm{E}_{2}-3 \mathrm{G}$ [40]. 
1 The rapid metabolism of exogenously administered estradiol to estrone, and partly to estriol, complicates

2 the determination of glucuronidation contribution to total estradiol metabolism and the subsequent

3 impact of different efflux transporters on the disposition of estradiol glucuronides [1, 39]. In addition,

4 particularly in the case of $\mathrm{E}_{2}-17 \mathrm{G}$, the hepatic uptake transporters may also play important roles in its

5 disposition, as indicated by the facts that there is only minor direct urinary excretion of $\mathrm{E}_{2}-17 \mathrm{G}$ when it

6 was administered, as such, via parenteral route, which is in line with findings using in vitro expressed

7 hepatic uptake transporters $[17,42] . \mathrm{E}_{2}-17 \mathrm{G}$ is known to be a substrate for all of the efflux transporters

8 included in this study [14], while the other glucuronide of estradiol, E2-3G, was transported by the same

9 transporters as $\mathrm{E}_{2}-17 \mathrm{G}$ except MRP4 in this study (Fig 2C).

Interestingly, none of the transporters appear to differ between transport of $\mathrm{E}_{1}-\mathrm{G}_{\text {and }} \mathrm{E}_{2}-3 \mathrm{G}$. However, the affinity of MRP3 toward $E_{1}-G$ and $E_{2}-3 G$, as suggested by its $K_{m}$ values for these glucuronides, is 10-fold higher than in the case of BCRP, while $\mathrm{K}_{\mathrm{m}}$ values of MRP2 for both glucuronides were rather high, suggesting poor affinity (Figs. $3 \mathrm{~A}, 4 \mathrm{~A}, 5 \mathrm{~A}$ and Table 1). Contrary to $\mathrm{E}_{2}-17 \mathrm{G}$, in the cases of $\mathrm{E}_{1}-3 \mathrm{G}$ and $\mathrm{E}_{2}-3 \mathrm{G}$ the hepatic uptake transporters might play less prominent roles and these glucuronides have been reported to be excreted mainly into urine from the blood circulation, without further enterohepatic circulation $[42,43]$. Thus, systemic excretion of $E_{1}-G$ and $E_{2}-3 G$ may be controlled by MRP3 in the basolateral membranes of intestine. Nevertheless, also apically expressed MRP2 and BCRP could contribute to the disposition of $\mathrm{E}_{1}-\mathrm{G}$ and $\mathrm{E}_{2}-3 \mathrm{G}$ (Figs. 2-6 and Table 1), especially in the intestine where these glucuronides are formed and both the above transporters are expressed $[12,38,40]$. It should be noted that UGT1A10 and MRP3 have higher and BCRP lower expression in the larger intestine than in the small intestine, which may mean that more $E_{1}-3 G$ and $E_{2}-3 G$ are formed in the distal intestine from unconjugated estrogens and subsequently these glucuronides are transported to the blood circulation by MRP3 [44, 45]. 
(Table 1)

\subsection{Transport and disposition of $\mathrm{E}_{3}-3 \mathrm{G}$ and $\mathrm{E}_{3}-16 \mathrm{G}$}

Estriol is considered to be an end product of estrogen metabolism (endogenous and exogenously administered) and it is extensively conjugated directly to $E_{3}-3 G$ and $E_{3}-16 G$ in the intestine, or only to $\mathrm{E}_{3}-16 \mathrm{G}$ in the liver $[1,5,46]$. After oral administration of estriol, the glucuronides circulate at relatively high levels, almost 1000-fold higher than the parent compound, until they are finally excreted into urine $[1,47,48]$. The enterohepatic circulation of estriol conjugates does not seem to be as extensive as for estradiol and estrone conjugates $[5,6,49]$. In the urine, $\mathrm{E}_{3}-16 \mathrm{G}$ is the major metabolite of estriol and the intestinal specific metabolite $\mathrm{E}_{3}-3 \mathrm{G}$ is present at about $10-20 \%$ of the total estriol $[50,51]$.

The observations above suggest that efflux transporters are responsible for most of the estriol glucuronide disposition. The predominant role of the basolateral efflux of estriol glucuronides is in line with our results (Figs. 2D and 2E and Table 1). We found that of the tested transporters, $\mathrm{E}_{3}-3 \mathrm{G}$ has a high affinity only to MRP3 (Fig. 5B and Table 1). This result supports the significance of basolateral excretion of this glucuronide from the human intestine. Based on our results, $\mathrm{E}_{3}-3 \mathrm{G}$ seems to be a rather specific substrate for MRP3 in the human small intestine. This may mean that oral administration of estriol, followed by plasma profiles of $\mathrm{E}_{3}-3 \mathrm{G}$, could serve as a marker for intestinal MRP3 function. Especially, because there is no indication of active uptake of $\mathrm{E}_{3}-3 \mathrm{G}$ into the liver or other tissues and this glucuronide is rapidly excreted into urine when it is administered to humans, as such [52]. In addition, larger intestine could be exposed to higher amounts of unconjugated estriol, which could result in high amounts of $\mathrm{E}_{3}-3 \mathrm{G}$, because of the enzymes catalyzing estriol glucuronidation, only UGT1A10 is expressed in this tissue [45, 46]. Significance of MRP3 in the disposition of E3-3G may be also high in the larger intestine, because its higher expression compared to the small intestine [44]. 
1 Although estriol carries two hydroxyl groups in the D ring, hepatic glucuronidation occurs only at the

2 hydroxyl in the 16 , not 17 position, resulting in the formation of $E_{3}-16 G$ [46]. We found a high affinity transport of $\mathrm{E}_{3}-16 \mathrm{G}$ by the basolateral transporter MRP3, whereas the affinity for $\mathrm{E}_{3}-16 \mathrm{G}$ by the other

4 5

rather highly expressed hepatic transporter, the apical MRP2, as far as suggested by the $\mathrm{K}_{\mathrm{m}}$ value, was low (Figs. 4B and 5B, Table 1). In addition, BCRP and MRP4 transported $\mathrm{E}_{3}-16 \mathrm{G}$ with moderate $\mathrm{K}_{\mathrm{m}}$ values (Figs. 2C and 2B, Table 1). Thus, it is likely that MRP3 is the main contributor to the disposition of $\mathrm{E}_{3}-16 \mathrm{G}$ from the liver, due to its lower $\mathrm{K}_{\mathrm{m}}$ value and higher expression level in comparison to MRP4 and BCRP [36]. Our results and the latter suggestion are supported by reported findings in humans that have indicated the predominant excretion route of $\mathrm{E}_{3}-16 \mathrm{G}$ to be into circulation and then subsequently to the urine, even if some $\mathrm{E}_{3}-16 \mathrm{G}$ is also excreted into bile [5, 6, 49-51]. However, how much each transporter contributes to the disposition of $\mathrm{E}_{3}-16 \mathrm{G}$ in the liver, is difficult to determine or predict, not least due to variability in expression levels of the different transporters in this tissue [36]. Especially MRP4 and BCRP are reported to be expressed at low levels in healthy human livers in comparison to MRP2 and MRP3 $[35,36]$. In addition, hepatic uptake transporters might also contribute to disposition of $\mathrm{E}_{3}-16 \mathrm{G}$, as indicated by some biliary excretion following its administration, as such, to humans via parenteral route $[49,53]$.

In humans, active kidney secretion of $\mathrm{E}_{3}-16 \mathrm{G}$ has been reported [47, 48]. Our in vitro results are in agreement with this, since $\mathrm{E}_{3}-16 \mathrm{G}$ was transported by both MRP2 and MRP4, two important kidney transporters $[12,13]$ (Fig. 2E and Table 1). The renal clearance of $\mathrm{E}_{3}-16 \mathrm{G}$ exceeds inulin clearance by 3-8 times, whereas the renal clearance of $\mathrm{E}_{3}-3 \mathrm{G}$ (not transported by MRP4, Fig. 2D) is only 1-2 times that of inulin clearance, when both conjugates are formed from endogenous estriol [47, 48]. However, estriol may also be glucuronidated, in vivo, in the human kidney to $\mathrm{E}_{3}-16 \mathrm{G}$, but not to $\mathrm{E}_{3}-3 \mathrm{G}$, a factor that complicates comparison between the renal clearances of these two glucuronides [54]. On the other 
1 hand, the ratio between estriol glucuronides and the parent compound in the blood circulation is

2 remarkably high, almost 1000, suggesting that the renal glucuronidation may only have a small impact,

3 and the high excretion of $E_{3}-16 G$ is a result of uptake from the circulation and subsequent efflux transport

4 in the kidney [1]. While MRP2 is also expressed on the apical membranes of proximal tubule cells [12],

5 the results of this study showed that the $K_{\mathrm{m}}$ value of MRP2 for the transport of $\mathrm{E}_{3}-16 \mathrm{G}$ is more than 10 -

6 fold higher than the corresponding value of MRP4 (Table 1), suggesting that MRP4 is likely to be play

7 a major role in the renal excretion of $E_{3}-16 G$.

8 It may be interesting that while each of the tested transporters exhibited rather similar activity and kinetics

9 toward both $\mathrm{E}_{1}-3 \mathrm{G}$ and $\mathrm{E}_{2}-3 \mathrm{G}$ (Figs. 3-5), two of the estrogens that carry glucuronic acid in the ring A,

this similarity does not extend to $\mathrm{E}_{3}-3 \mathrm{G}$, even though its glucuronic acid is in the exact same position as

11 in $E_{1}-3 G$ and $E_{2}-3 G$ (Fig. 1). The difference between transport of $E_{1}-3 G_{1}, E_{2}-3 G$ and $E_{3}-3 G$ is most obvious in the case of BCRP (Figs. 2D and 3C, and Table 1), but is also seen in MRP2. MRP3, in contrast

to BCRP and MRP2, was only little affected by the substrate change to $E_{3}-3 G$, even if its $K_{m}$ value in this case was somewhat higher than for any other of the glucuronides in this study, including $\mathrm{E}_{3}-16 \mathrm{G}$ (Table 1). While it is currently unclear why the differences between estradiol and estriol have strong effect on BCRP and MRP2, this might provide a tool to explore the structure of the binding sites of these transporters and understand similarities and differences between them.

\section{Summary}

We have studied here the efflux transport of $E_{1}-G, E_{2}-3 G, E_{3}-3 G, E_{3}-16 G$ and $E_{1}-S$ by recombinant human transporters MRP2, MRP3, MRP4 and BCRP, using inside-out membrane vesicles. We found the highest transport activity of BCRP toward $E_{1}-G$ and $E_{2}-3 G$ and lower to $E_{1}-S$. While $E_{1}-S$ was a specific substrate for BCRP, $\mathrm{E}_{1}-\mathrm{G}$ and $\mathrm{E}_{2}-3 \mathrm{G}$ were transported by BCRP at much higher rates, but at lower apparent affinity than $\mathrm{E}_{1}-\mathrm{S}$. MRP2 exhibited low affinity and MRP3 rather high transport affinity to all 
1 the tested estrogen glucuronides, but at moderate rates. As a result, $\mathrm{E}_{3}-3 \mathrm{G}$ was efficiently transported

2 almost only by MRP3. From the tested estrogen glucuronides, MRP4 transported only E3-16G. Our

3 results provide new details and in vitro explanations for most of the already known in vivo disposition

4 data of estrogens, thereby improving our understanding of how these estrogen glucuronides are disposed 5 in humans and what are the underlying molecular mechanisms.

6

\section{ACKNOWLEDGEMENTS}

8 We would like to thank Johanna Mosorin for her skillful help in the transport vesicle preparations and $9 \quad$ Noora Sjöstedt for preliminary transport experiments.

The funding from the University of Helsinki Doctoral Program in Drug Research, Sigrid Juselius

11 Foundation (grant no. 4704583) and the Academy of Finland (grant no. 292779) are acknowledged. 
1 Table 1. Kinetic constants for the studied estrogen conjugates and transporters.

\begin{tabular}{|c|c|c|c|}
\hline Compound & $\begin{array}{c}\boldsymbol{K}_{\mathbf{m}} \\
\mu \mathrm{M}(95 \% \mathrm{CI})\end{array}$ & $\begin{array}{c}\boldsymbol{V}_{\max } \\
\mathrm{pmol} / \mathrm{mg} / \min (95 \% \mathrm{CI})\end{array}$ & $R^{2}$ \\
\hline \multicolumn{4}{|c|}{ MRP2 } \\
\hline $\mathbf{E}_{1}-\mathbf{G}$ & $241(210-273)$ & 884 (830-938) & 0.99 \\
\hline $\mathrm{E}_{2-3 G}$ & $180(145-216)$ & $1700(1560-1840)$ & 0.97 \\
\hline$E_{3-3 G}$ & $791(640-942)$ & $1800(1560-2030)$ & 0.99 \\
\hline $\mathrm{E}_{3-16} \mathrm{G}$ & 773 (596-949) & $6440(5330-7540)$ & 0.98 \\
\hline \multicolumn{4}{|c|}{ MRP3 } \\
\hline $\mathbf{E}_{1-G}$ & $7.3(5.6-8.9)$ & $182(171-194)$ & $\begin{array}{c}7 \\
0.92\end{array}$ \\
\hline$E_{2-3 G}$ & $2.8(2.0-3.6)$ & $260(245-274)$ & 0.86 \\
\hline$E_{3-3 G}$ & $18(16-21)$ & $441(419-463)$ & 0.98 \\
\hline $\mathrm{E}_{3-16 G}$ & $4.8(3.4-6.3)$ & $195(180-211)$ & 0.90 \\
\hline \multicolumn{4}{|c|}{ MRP4 } \\
\hline $\mathrm{E}_{3-16} \mathrm{G}$ & $65(53-77)$ & $522(491-554)$ & 0.96 \\
\hline \multicolumn{3}{|c|}{ BCRP } & 11 \\
\hline $\mathbf{E}_{1-G}$ & $74(65-82)$ & $9310(8940-9690)$ & 0.99 \\
\hline $\mathrm{E}_{2-3 G}$ & $81(50-112)$ & 7910 (7010-8810) & 0.88 \\
\hline $\mathbf{E}_{\mathbf{3}-3 G}$ & $1020(736-1300)$ & $4410(3500-5320)$ & 0199 \\
\hline $\mathrm{E}_{3-16} \mathbf{G}$ & $29(21-37)$ & $1080(1000-1170)$ & 0.92 \\
\hline$E_{1-S}$ & $1.2(0.78-1.7)$ & 817 (745-889) & $\begin{array}{l}14 \\
0.83\end{array}$ \\
\hline
\end{tabular}

15 The kinetic parameters are derived from the experimental data, presented in Figures 3-5, fitted in the Michaelis-Menten equation. The $95 \%$ confidence intervals (CI) for the derived kinetic values are presented in the parentheses. For the experimental details, see Figures 3-5. 


\section{FIGURE LEGENDS}

\section{Fig. 1. Structures of the estrogen conjugates.}

Structures of the studied glucuronides of estrone, estradiol and estriol, estrone sulfate and $\mathrm{E}_{2}-17 \mathrm{G}$.

\section{Fig. 2. Screening results of E1-S, E1-G, E2-3G, E3-3G and E3-16G transport.}

Transport of $E_{1}-S(A), E_{1}-G(B), E_{2}-3 G(C), E_{3}-3 G(D)$ and $E_{3}-16 G(E)$ by MRP2, MRP3, MRP4, MDR1 and BCRP was studied using $10 \mu \mathrm{M}$ substrate concentration and 2 min incubation. The transport assays were conducted in the presence (colored bars) or absence (open bars) of ATP, and contained $40 \mu \mathrm{g}$ (MRPs, MDR1 and $\mathrm{Ctrl}^{\mathrm{M}}$ ) or $20 \mu \mathrm{g}\left(\mathrm{BCRP}\right.$ and $\mathrm{Ctrl}^{+\mathrm{C}}$ ) of total vesicle protein per sample. Control vesicles, containing no human transporter, were included in all assays and are presented as $\mathrm{Ctrl}^{\mathrm{M}}$ for MRPs, or $\mathrm{Ctrl}^{+\mathrm{C}}$ for MDR1 and BCRP (MDR1, BCRP and $\mathrm{Ctrl}^{+\mathrm{C}}$ vesicles were supplemented with cholesterol, see section 2.2). The presented results are from a single experiment that was conducted in triplicate samples, and the error bars represent \pm SD.

\section{Fig. 3. BCRP transport kinetics of E1-S, E1-G, E2-3G, E3-3G and E3-16G.}

The ATP-dependent BCRP transport kinetics of $E_{1}-G$ and $E_{2}-3 G(A), E_{1}-S(B)$ and $E_{3}-3 G$ and $E_{3}-16 G$ (C) were studied during $1 \mathrm{~min}\left(\mathrm{E}_{1}-\mathrm{S}\right), 2 \mathrm{~min}\left(\mathrm{E}_{1}-\mathrm{G}, \mathrm{E}_{2}-3 \mathrm{G}\right.$ and $\left.\mathrm{E}_{3}-16 \mathrm{G}\right)$ or $6 \mathrm{~min}\left(\mathrm{E}_{3}-3 \mathrm{G}\right)$ incubations. In each sample, the total vesicle protein amount was $20 \mu \mathrm{g}$. The fitted model was the Michaelis-Menten equation and the fitting is presented by the lines. The data points represent means of the ATP-dependent values $\pm \mathrm{SD}$, from a single experiment conducted in triplicate samples.

\section{Fig. 4. MRP2 transport kinetics of $E_{1}-G, E_{2}-3 G, E_{3}-3 G$ and $E_{3}-16 G$.}

The ATP-dependent MRP2 transport kinetics of $\mathrm{E}_{1}-\mathrm{G}$ and $\mathrm{E}_{2}-3 \mathrm{G}(\mathrm{A})$, as well as $\mathrm{E}_{3}-3 \mathrm{G}$ and $\mathrm{E}_{3}-16 \mathrm{G}$ (B), were assayed either for $2 \min \left(E_{2}-3 G\right.$ and $\left.E_{3}-16 G\right)$ or 6 min $\left(E_{1}-G\right.$ and $\left.E_{3}-3 G\right)$. In each sample, the total 
1 vesicle protein amount was $40 \mu \mathrm{g}$. The fitted model was the Michaelis-Menten equation and the fitting

2 is presented by the lines. The data points represent means of the ATP-dependent values \pm SD from a 3 single experiment conducted in triplicate samples.

\section{Fig. 5. MRP3 transport kinetics of E1-G, E2-3G, E3-3G and E3-16G, and MRP4 transport kinetics}

\section{5 of $\mathbf{E}_{3}-\mathbf{1 6 G}$.}

The ATP-dependent MRP3 transport kinetics of $E_{1}-G$ and $E_{2}-3 G(A)$, as well as $E_{3}-3 G$ and $E_{3}-16 G(B)$, were assayed for either $1 \mathrm{~min}\left(\mathrm{E}_{2}-3 \mathrm{G}\right)$ or $2 \mathrm{~min}\left(\mathrm{E}_{1}-\mathrm{G}, \mathrm{E}_{3}-3 \mathrm{G}\right.$ and $\left.\mathrm{E}_{3}-16 \mathrm{G}\right)$. The ATP-dependent MRP4 transport kinetics of $\mathrm{E}_{3}-16 \mathrm{G}(\mathrm{C})$ was studied using 2 min incubation. In each sample, the total vesicle protein amount was $40 \mu \mathrm{g}$. The fitted model was the Michaelis-Menten equation and the fitting is presented by the lines. The data points represent means of the ATP-dependent values \pm SD from a single experiment conducted in triplicate samples.

\section{Fig. 6. Disposition human estrogen conjugates; a schematic presentation based on a combination} of new and previous results.

Transporters are represented as white arrows, the width of which indicates whether it is relatively highly or lowly expressed in the tissue and dashed outlines stand for speculative transporters or mechanisms that have limited evidence. The liver image stands for a typical hepatocyte. Conjugated and unconjugated estrogens are represented by abbreviations containing numbers and letters. The compounds abbreviation denotes the type of estrogen (E1, E2, and E3 standing for estrone, estradiol, and estriol) and the latter part describes the conjugation position and the type of conjugate, as in the text. Larger compound names indicate higher transport rates of the given substrate by the specific transporter. Black arrows inside the cells represent estrogen biotransformation reactions and the relative extent of these reactions.

$[1,6,15-17,22,36-38,40,41,44,46-48,54,55]$ 
1 Supplementary materials:

2

3 Figure S1: Eadie-Hofstee transformations of the data presented in Figures 3-5

$4 \quad$ Figure S2: Transport versus time of the studied estrogen conjugates and transporters 


\section{REFERENCES}

2 [1] H. Kuhl, Pharmacology of estrogens and progestogens: Influence of different routes of 3 administration. Climacteric 8 (SUPPL. 1) (2005) 3-63.

4 [2] R.J. Ruggiero, F.E. Likis, Estrogen: Physiology, pharmacology, and formulations for replacement 5 therapy. J. Midwifery Women's Health 47 (3) (2002) 130-137.

6 [3] B.T. Zhu, A.H. Conney, Functional role of estrogen metabolism in target cells: Review and 7 perspectives. Carcinogenesis 19 (1) (1998) 1-27.

8 [4] R. Raftogianis, C. Creveling, R. Weinshilboum, J. Weisz, Estrogen metabolism by conjugation. J. $9 \quad$ Natl. Cancer Inst. Monographs (27) (2000) 113-124.

[5] H. Adlercreutz, F. Martin, P. Järvenpää, T. Fotsis, Steroid absorption and enterohepatic recycling. 11 Contraception 20 (3) (1979) 201-223.

[6] H. Adlercreutz, F. Martin, Biliary excretion and intestinal metabolism of progesterone and estrogens 13 in man. J. Steroid Biochem. 13 (2) (1980) 231-244.

[7] É. Audet-Walsh, J. Lépine, J. Grégoire, M. Plante, P. Caron, B. Têtu, P. Ayotte, J. Brisson, L.

Villeneuve, A. Bélanger, C. Guillemette, Profiling of endogenous estrogens, their precursors, and metabolites in endometrial cancer patients: Association with risk and relationship to clinical characteristics. J. Clin. Endocrinol. Metab. 96 (2) (2011).

[8] Y. Zhao, J.M. Boyd, M.B. Sawyer, X.-. Li, Liquid chromatography tandem mass spectrometry determination of free and conjugated estrogens in breast cancer patients before and after exemestane treatment. Anal. Chim. Acta 806 (2014) 172-179. 
1 [9] F. Andreolini, C. Borra, F. Caccamo, A.D. Corcia, R. Samperi, Estrogen Conjugates in Late-

2 Pregnancy Fluids: Extraction and Group Separation by a Graphitized Carbon Black Cartridge and 3 Quantification by High-Performance Liquid Chromatography. Anal. Chem. 59 (13) (1987) 1720-1725.

4 [10] V. Vasiliou, K. Vasiliou, D.W. Nebert, Human ATP-binding cassette (ABC) transporter family. $5 \quad$ Hum. Genomics 3 (3) (2009) 281-290.

6 [11] A.H. Schinkel, J.W. Jonker, Mammalian drug efflux transporters of the ATP binding cassette (ABC) 7 family: An overview. Adv. Drug Deliv. Rev. 55 (1) (2003) 3-29.

8 [12] K.M. Giacomini, S.-. Huang, D.J. Tweedie, L.Z. Benet, K.L.R. Brouwer, X. Chu, A. Dahlin, R. 9 Evers, V. Fischer, K.M. Hillgren, K.A. Hoffmaster, T. Ishikawa, D. Keppler, R.B. Kim, C.A. Lee, M. 10 Niemi, J.W. Polli, Y. Sugiyama, P.W. Swaan, J.A. Ware, S.H. Wright, S. Wah Yee, M.J. Zamek-

Gliszczynski, L. Zhang, Membrane transporters in drug development. Nat. Rev. Drug Discov. 9 (3) 12 (2010) 215-236.

[13] K.M. Hillgren, D. Keppler, A.A. Zur, K.M. Giacomini, B. Stieger, C.E. Cass, L. Zhang, Emerging 14 transporters of clinical importance: An update from the international transporter consortium. Clin. Pharmacol. Ther. 94 (1) (2013) 52-63.

[14] M.J. Zamek-Gliszczynski, K.A. Hoffmaster, K.-. Nezasa, M.N. Tallman, K.L.R. Brouwer, Integration of hepatic drug transporters and phase II metabolizing enzymes: Mechanisms of hepatic excretion of sulfate, glucuronide, and glutathione metabolites. Eur. J. Pharm. Sci. 27 (5) (2006) 447-486.

[15] D.R. De Waart, K. Van De Wetering, C. Kunne, S. Duijst, C.C. Paulusma, R.P.J. Oude Elferink, 20 Oral availability of cefadroxil depends on ABCC3 and ABCC4. Drug Metab. Dispos. 40 (3) (2012) 515521. 
1 [16] X. Ming, D.R. Thakker, Role of basolateral efflux transporter MRP4 in the intestinal absorption of

2 the antiviral drug adefovir dipivoxil. Biochem. Pharmacol. 79 (3) (2010) 455-462.

3

4

5

6 $7 \quad 1371-1377$.

8

9 $100-105$.

[17] M. Roth, A. Obaidat, B. Hagenbuch, OATPs, OATs and OCTs: The organic anion and cation transporters of the SLCO and SLC22A gene superfamilies. Br. J. Pharmacol. 165 (5) (2012) 1260-1287.

[18] L. Huang, T. Hoffman, M. Vore, Adenosine triphosphate-dependent transport of estradiol-17ß (ßD- glucuronide) in membrane vesicles by MDR1 expressed in insect cells. Hepatology 28 (5) (1998)

[19] P.M. Gerk, W. Li, V. Megaraj, M. Vore, Human multidrug resistance protein 2 transports the therapeutic bile salt tauroursodeoxycholate. J. Pharmacol. Exp. Ther. 320 (2) (2007) 893-899.

[20] H. Kidron, G. Wissel, N. Manevski, M. Häkli, R.A. Ketola, M. Finel, M. Yliperttula, H. Xhaard, A. Urtti, Impact of probe compound in MRP2 vesicular transport assays. Eur. J. Pharm. Sci. 46 (1-2) (2012)

[21] F. Deng, N. Sjostedt, H. Kidron, The Effect of Albumin on MRP2 and BCRP in the Vesicular Transport Assay. PLoS One 11 (10) (2016).

[22] E. Järvinen, J. Troberg, H. Kidron, M. Finel, Selectivity in the efflux of glucuronides by human transporters MRP4 is highly active toward 4-methylumbelliferone and 1-naphthol glucuronides, while MRP3 exhibits stereoselective propranolol glucuronide transport. Mol. Pharm. (2017).

[23] N. Sjöstedt, K. Holvikari, P. Tammela, H. Kidron, Inhibition of Breast Cancer Resistance Protein and Multidrug Resistance Associated Protein 2 by Natural Compounds and Their Derivatives. Mol. Pharm. 14 (1) (2017) 135-146. 
1 [24] N. Sjostedt, F. Deng, O. Rauvala, T. Tepponen, H. Kidron, Interaction of Food Additives with 2 Intestinal Efflux Transporters. Mol. Pharm. (2017).

[25] Á. Telbisz, M. Müller, C. Özvegy-Laczka, L. Homolya, L. Szente, A. Váradi, B. Sarkadi, Membrane cholesterol selectively modulates the activity of the human ABCG2 multidrug transporter. Biochim. Biophys. Acta Biomembr. 1768 (11) (2007) 2698-2713.

[26] K. Herédi-Szabó, J.E. Palm, T.B. Andersson, Á. Pál, D. Méhn, Z. Fekete, E. Beéry, K.T. Jakab, M. Jani, P. Krajcsi, A P-gp vesicular transport inhibition assay - Optimization and validation for drug-drug interaction testing. Eur. J. Pharm. Sci. 49 (4) (2013) 773-781.

[27] Y. Imai, S. Asada, S. Tsukahara, E. Ishikawa, T. Tsuruo, Y. Sugimoto, Breast cancer resistance protein exports sulfated estrogens but not free estrogens. Mol. Pharmacol. 64 (3) (2003) 610-618.

[28] P.E. Bandler, C.J. Westlake, C.E. Grant, S.P.C. Cole, R.G. Deeley, Identification of regions required for apical membrane localization of human multidrug resistance protein 2. Mol. Pharmacol. 74 (1) (2008) 9-19.

[29] C.E. Grant, M. Gao, M.K. DeGorter, S.P.C. Cole, R.G. Deeley, Structural determinants of substrate specificity differences between human multidrug resistance protein (MRP) 1 (ABCC1) and MRP3 (ABCC3). Drug Metab. Dispos. 36 (12) (2008) 2571-2581.

[30] Y.-. Han, D. Busler, Y. Hong, Y. Tian, C. Chen, A.D. Rodrigues, Transporter studies with the 3-Osulfate conjugate of 17a- ethinylestradiol: Assessment of human kidney drug transporters. Drug Metab. Dispos. 38 (7) (2010) 1064-1071.

[31] Y.-. Han, D. Busler, Y. Hong, Y. Tian, C. Chen, A.D. Rodrigues, Transporter studies with the 3-Osulfate conjugate of 17a- ethinylestradiol: Assessment of human liver drug transporters. Drug Metab. Dispos. 38 (7) (2010) 1072-1082. 
1 [32] H. Jirku, M. Levitz, Biliary and urinary metabolites of estrone-6,7-3H-sulfate-35S in a woman. J. 2 Clin. Endocrinol. Metab. 29 (5) (1969) 615-637.

3 [33] Y.-. Qian, W.-. Song, H. Cui, S.P.C. Cole, R.G. Deeley, Glutathione Stimulates Sulfated Estrogen

4 Transport by Multidrug Resistance Protein 1. J. Biol. Chem. 276 (9) (2001) 6404-6411.

5 [34] D.J. Seward, A.S. Koh, J.L. Boyer, N. Ballatori, Functional complementation between a novel 6 mammalian polygenic transport complex and an evolutionarily ancient organic solute transporter, OST $\alpha$ 7 OST $\beta$. J. Biol. Chem. 278 (30) (2003) 27473-27482.

[35] V.R. More, Q. Cheng, A.C. Donepudi, D.B. Buckley, Z.J. Lu, N.J. Cherrington, A.L. Slitt, Alcohol

9 cirrhosis alters nuclear receptor and drug transporter expression in human livers. Drug Metab. Dispos. $10 \quad 41(5)(2013) 1148-1155$.

11 [36] H.J. Burt, A.E. Riedmaier, M.D. Harwood, H.K. Crewe, K.L. Gill, S. Neuhoff, Abundance of hepatic transporters in Caucasians: A meta-analysis. Drug Metab. Dispos. 44 (10) (2016) 1550-1561.

[37] N. Gamage, A. Barnett, N. Hempel, R.G. Duggleby, K.F. Windmill, J.L. Martin, M.E. McManus, Human sulfotransferases and their role in chemical metabolism. Toxicol. Sci. 90 (1) (2006) 5-22.

[38] R.A. Kallionpää, E. Järvinen, M. Finel, Glucuronidation of estrone and 16a-hydroxyestrone by human UGT enzymes: The key roles of UGT1A10 and UGT2B7. J. Steroid Biochem. Mol. Biol. 154 17 (2015) 104-111.

[39] C. Longcope, S. Gorbach, B. Goldin, M. Woods, J. Dwyer, A. Morrill, J. Warram, The Effect of a 19

Low Fat Diet on Estrogen Metabolism. J. Clin. Endocrinol. Metab. 64 (6) (1987) 1246-1250. 
1 [40] R. Hobkirk, M. Nilsen, Metabolism of 17ß-estradiol to 17ß-estradiol- 3-glucosiduronate and 17ß-

2 estradiol-17-glucosiduronate by the normal human female. J. Clin. Endocrinol. Metab. 32 (6) (1971) 779-

3785.

4 [41] M.B. Fisher, K. Campanale, B.L. Ackermann, M. Vandenbranden, S.A. Wrighton, In vitro 5 glucuronidation using human liver microsomes and the pore- forming peptide alamethicin. Drug Metab. $6 \quad$ Dispos. $28(5)(2000) 560-566$.

7 [42] P.I. Musey, R.N. Green, R. Hobkirk, The role of an enterohepatic system in the metabolism of 17ß8 estradiol-17-glucosiduronate in the human female. J. Clin. Endocrinol. Metab. 35 (3) (1972) 448-457.

[43] R. Hobkirk, M. Nilsen, Metabolism of estrone-3-glucosiduronate and 17ß-estradiol-310 glucosiduronate in the human female. Steroids 15 (5) (1970) 649-667.

[44] M. Drozdzik, C. Gröer, J. Penski, J. Lapczuk, M. Ostrowski, Y. Lai, B. Prasad, J.D. Unadkat, W.

Siegmund, S. Oswald, Protein abundance of clinically relevant multidrug transporters along the entire length of the human intestine. Mol. Pharm. 11 (10) (2014) 3547-3555.

[45] G.N. Asher, J.K. Fallon, P.C. Smith, UGT concentrations in human rectal tissue after multidose, oral curcumin. Pharmacol. Res. Perspect. 4 (2) (2016).

[46] N. Sneitz, M. Vahermo, J. Mosorin, L. Laakkonen, D. Poirier, M. Finel, Regiospecificity and stereospecificity of human udpglucuronosyltransferases in the glucuronidation of estriol, 16-epiestriol, 17-epiestriol, and 13-epiestradiols. Drug Metab. Dispos. 41 (3) (2013) 582-591. pregnancy at term. Am. J. Obstet. Gynecol. 126 (1) (1976) 38-42. 
1 [48] M. Levitz, S. Kadner, B.K. Young, Intermediary metabolism of estriol in pregnancy. J. Steroid 2 Biochem. 20 (4 PART 2) (1984) 971-974.

3

[49] A.A. Sandberg, W.R. Slaunwhite Jr., Studies on phenolic steroids in human subjects. VII. Metabolic fate of. J. Clin. Invest. 44 (1965) 694-702.

[50] U. Goebelsmann, K. Sjöberg, N. Wiqvist, E. Diczfalusy, Oestriol-3-glucosiduronate, a major urinary metabolite of oestriol and oestriol-16(17?)-glucosiduronate. Acta Endocrinol (Copenh) 50 (2) (1965) 261-272.

[51] K.F. Stoa, M. Levitz, Comparison of the conjugated metabolites of intravenously and intraduodenally administered oestriol. Acta Endocrinol (Copenh) 57 (4) (1968) 657-668.

[52] R.Y. Kirdani, W.R. Slaunwhite Jr., A.A. Sandberg, Studies on phenolic steroids in human subjects. XIV. Studies on the fate of injected 6,7-H3-oestriol-3-C14-glucosiduronate. J. Steroid Biochem. 1 (4) (1970) 265-278.

[53] N. Inoue, A.A. Sandberg, J.B. Graham, W.R. Slaunwhite Jr., Studies on phenolic steroids in human subjects. 8. Metabolism of estriol-16 alpha-glucosiduronate. J. Clin. Invest. 48 (2) (1969) 380-389.

[54] R.Y. Kirdani, D. Sampson, G.P. Murphy, A.A. Sandberg, Studies on phenolic steroids in human subjects. XVI. role of the kidney in the disposition of estriol. J. Clin. Endocrinol. Metab. 34 (3) (1972) 546-557.

[55] B. Prasad, K. Johnson, S. Billington, C. Lee, G.W. Chung, C.D.A. Brown, E.J. Kelly, J. Himmelfarb, J.D. Unadkat, Abundance of drug transporters in the human kidney cortex as quantified by quantitative targeted proteomics. Drug Metab. Dispos. 44 (12) (2016) 1920-1924. 
$1 \quad$ Figure 1

estrone-3-glucuronide ( $\left.E_{1}-G\right)$

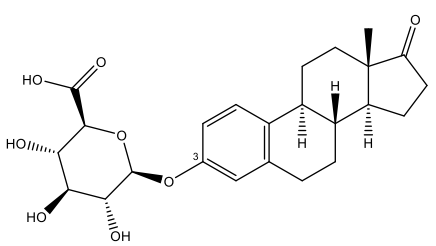

estrone-3-sulfate $\left(E_{1}-S\right)$

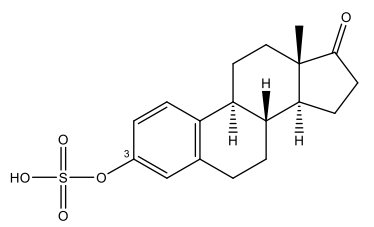

estradiol-3-glucuronide ( $\left.\mathrm{E}_{2}-3 \mathrm{G}\right)$

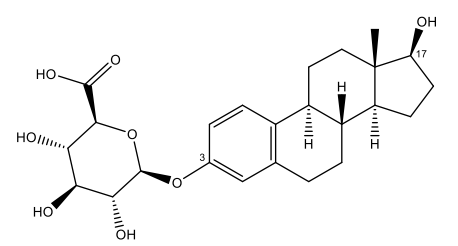

estradiol-17ß-glucuronide ( $\left.\mathrm{E}_{2}-17 \mathrm{G}\right)$

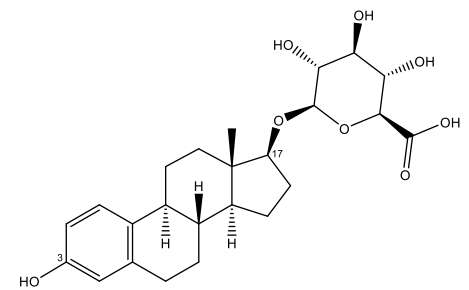

estriol-3-glucuronide ( $\left.\mathrm{E}_{3}-3 \mathrm{G}\right)$

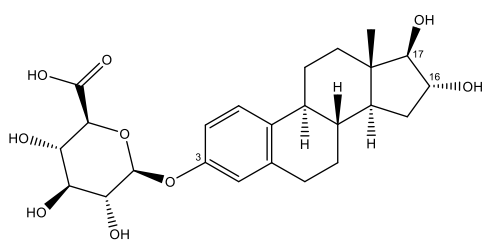

estriol-16 $\alpha$-glucuronide $\left(\mathrm{E}_{3}-16 \mathrm{G}\right)$

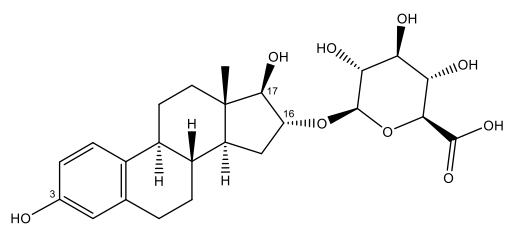

3 
Figure 2

2
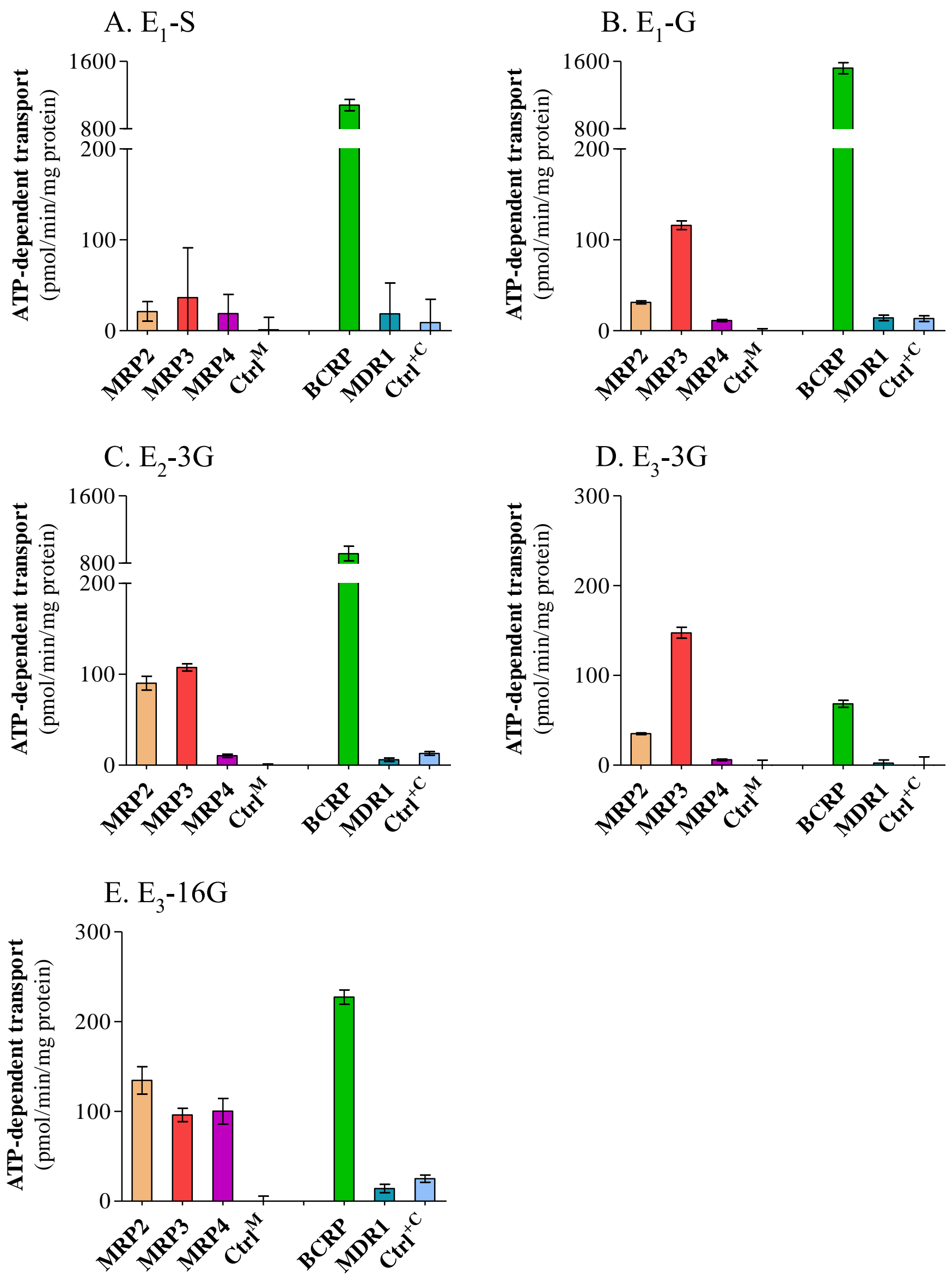
$1 \quad$ Figure 3

2

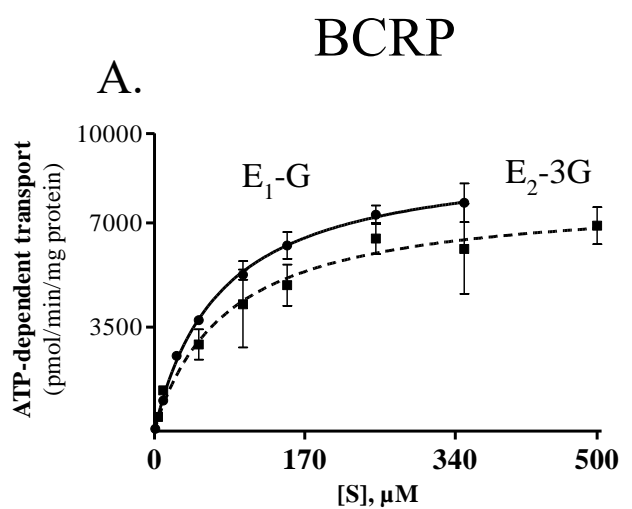

B.

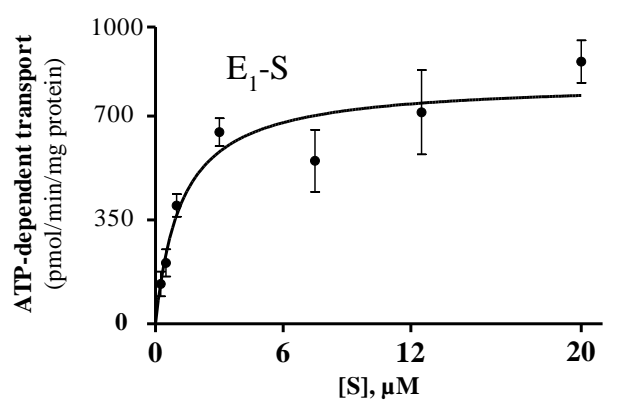

C.

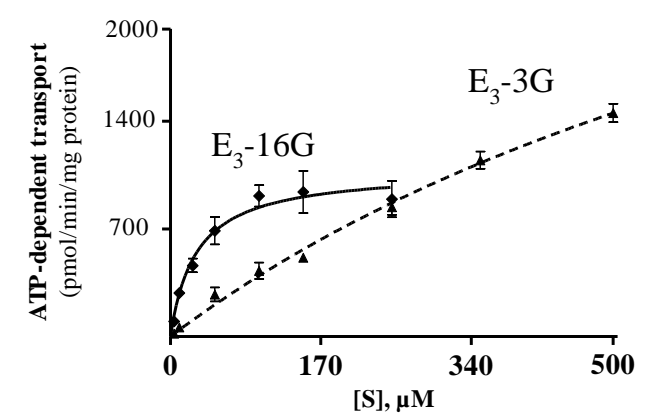


1 Figure 4

2

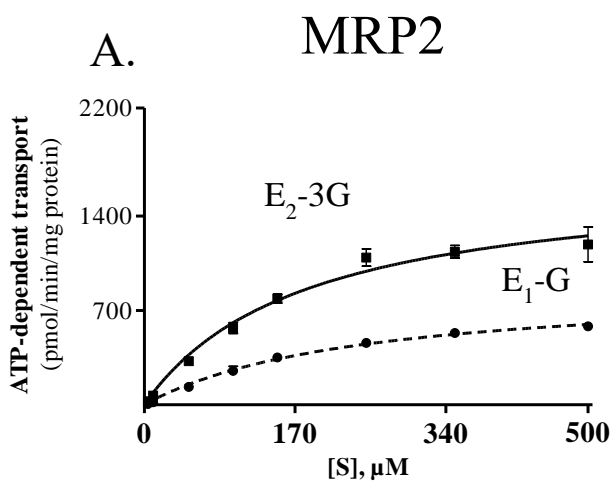

B.

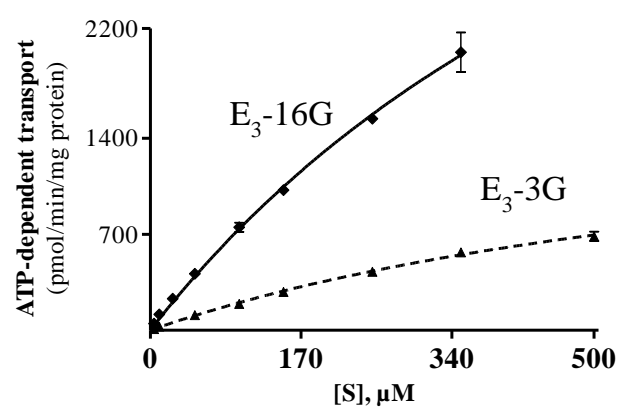


1 Figure 5

2

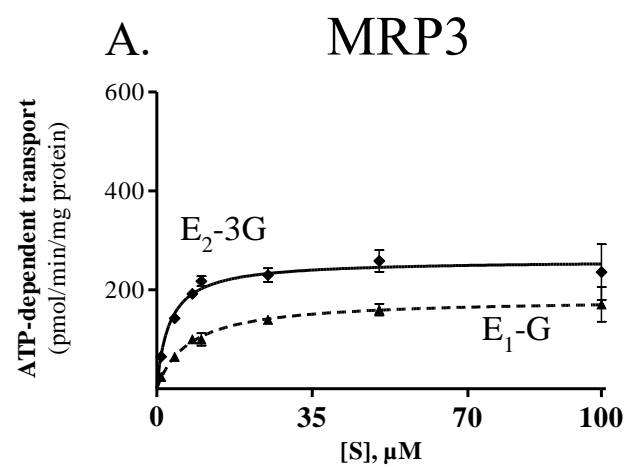

B.

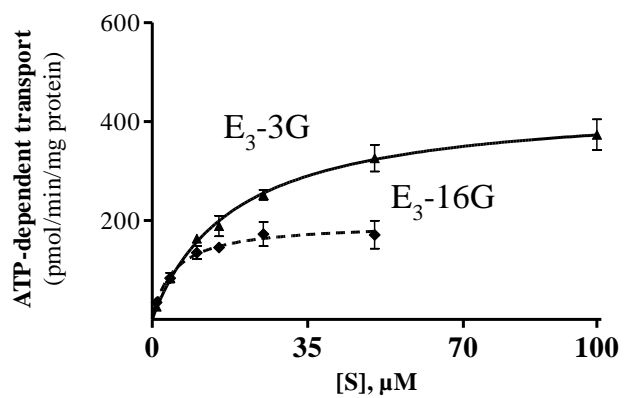

C. MRP4

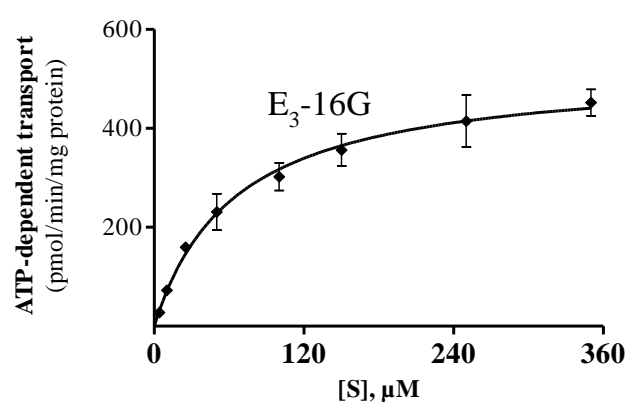


1 Figure 6

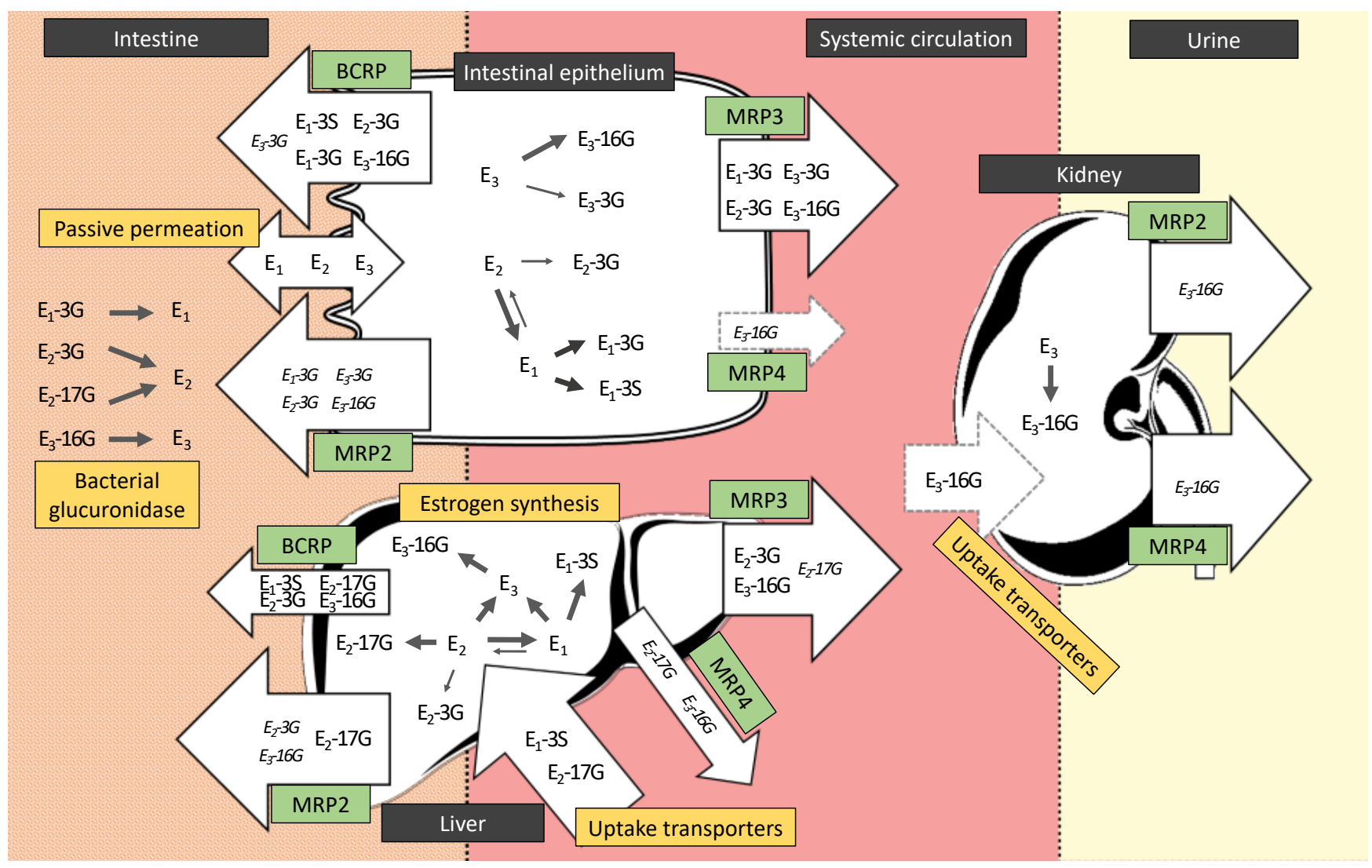



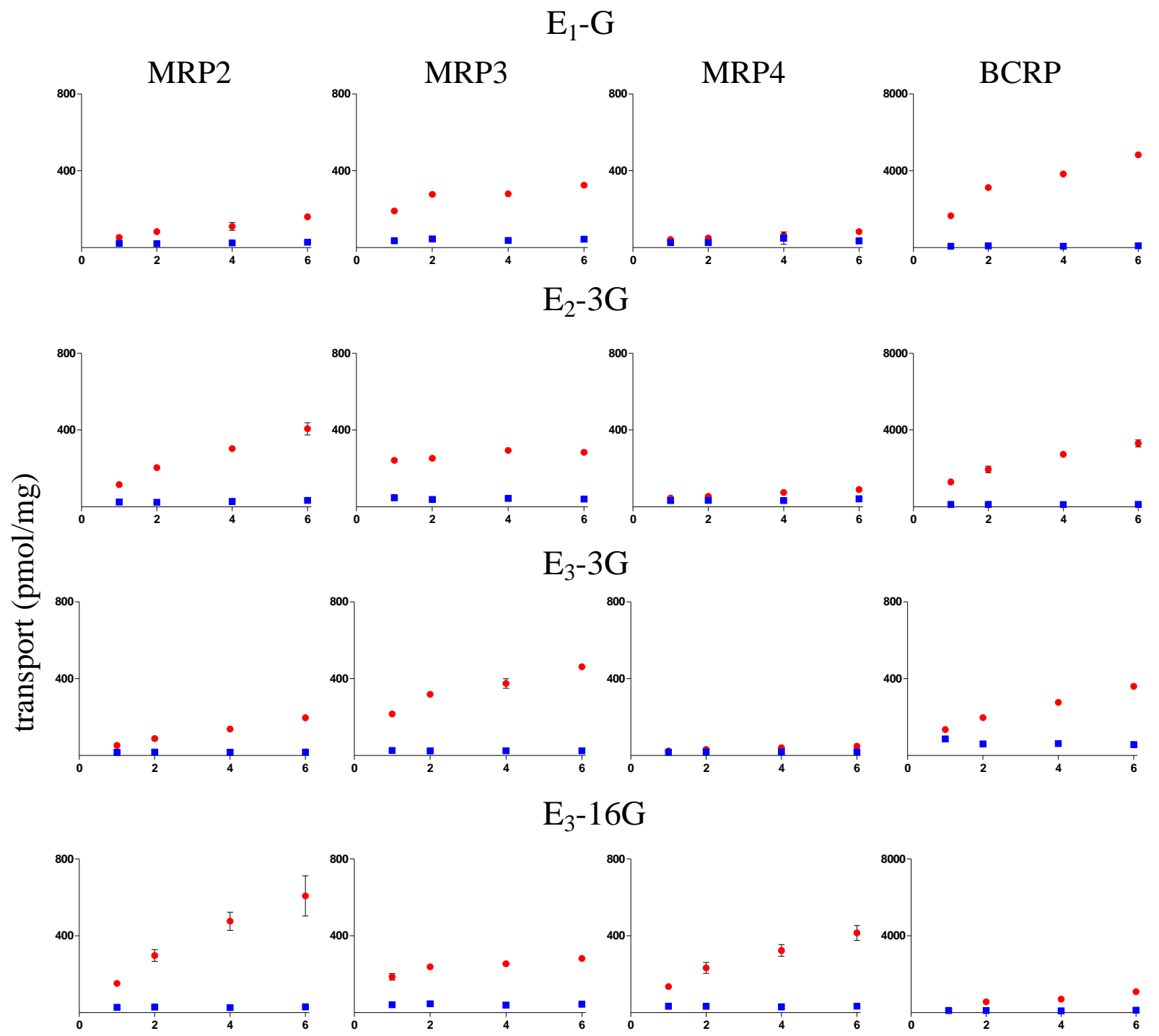

$\mathrm{E}_{1}-\mathrm{S}$
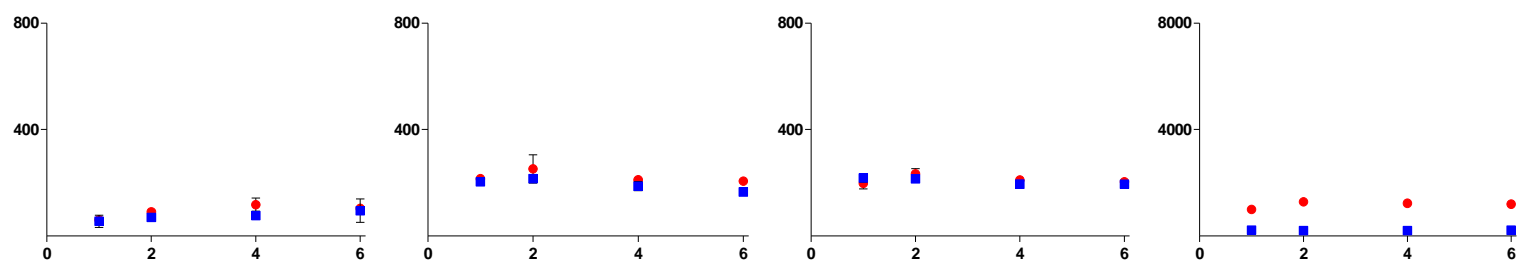

- +ATP - -ATP

time (min)

Suppl. Fig. 1 
MRP2
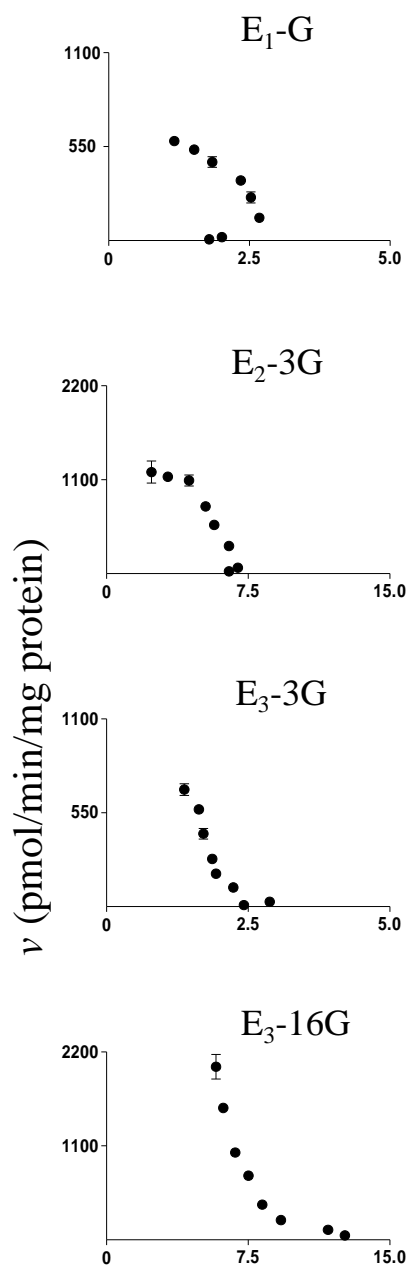

MRP3
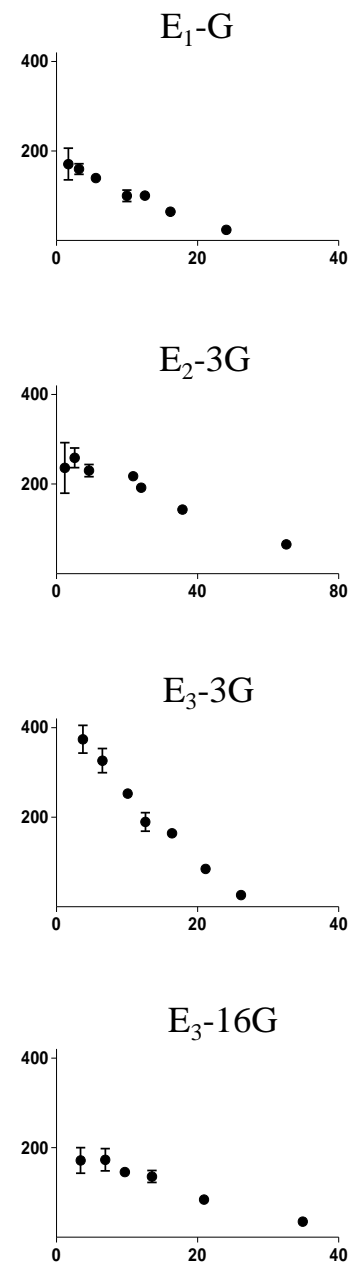

BCRP
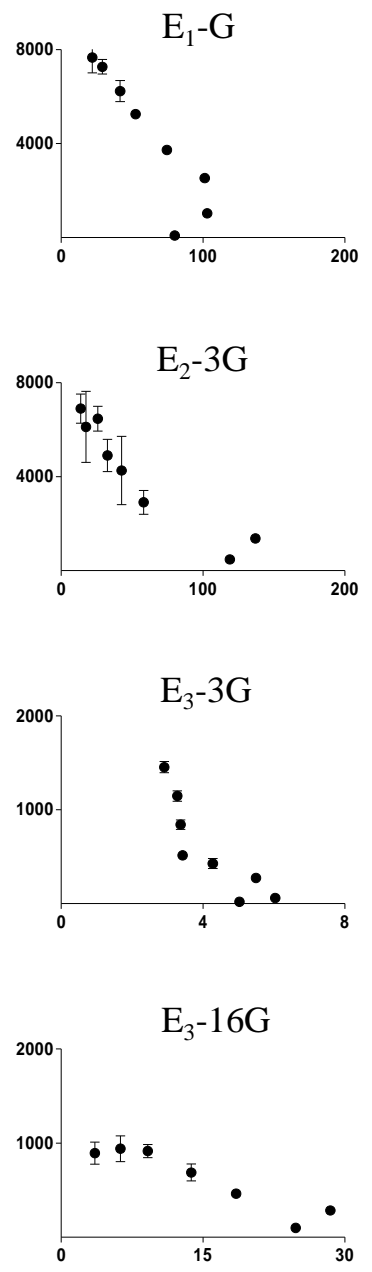
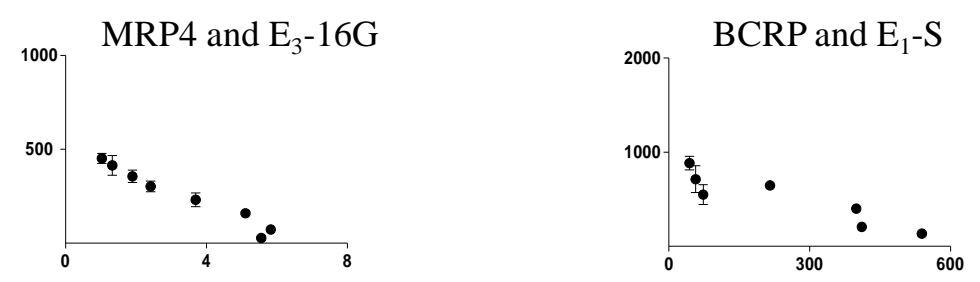

$[\mathrm{S}] / v(\mu \mathrm{M} / \mathrm{pmol} / \mathrm{min} / \mathrm{mg}$ protein $)$

Fig S2. Eadie-Hofstee transformations of the data presented in Figures 3-5. For further details see the Figures 3-5 in the main text. 